\title{
Stereoselective Enolizations Mediated by Magnesium and Calcium Bisamides: Contrasting Aggregation Behavior in Solution and in the Solid State
}

\author{
Xuyang He, John F. Allan, ${ }^{\dagger}$ Bruce C. Noll, ${ }^{\dagger}$ Alan R. Kennedy, ${ }^{\ddagger}$ and Kenneth W. \\ Henderson $^{* \dagger}$ \\ ${ }^{\dagger}$ Department of Chemistry and Biochemistry, University of Notre Dame, Notre Dame, IN 46556. \\ 'Department of Pure and Applied Chemistry, University of Strathclyde, Glasgow, Scotland, UK.
}

E-mail:khenders@nd.edu

\section{General Procedures}

All operations were carried out using Schlenk techniques or inside an argon-filled glove box. All glassware was flame-dried under vacuum before use. Solvents were dried by passage through copper-based catalyst and/or molecular sieve columns (Innovative Technology). KHMDS was purchased from Aldrich and used as received. Propiophenone and TMSCl were rigorously dried and distilled under a $\mathrm{N}_{2}$ atmosphere before use. $\mathrm{Ca}(\mathrm{HMDS})_{2}$ prepared by the reaction of 2 equiv KHMDS with $\mathrm{CaI}_{2}$.T 1 Crystalline $\mathrm{Mg}(\mathrm{HMDS})_{2}$ was prepared by the reaction of $\mathrm{Bu}_{2} \mathrm{Mg}$ with 2 equiv of $\operatorname{HMDS}(\mathrm{H})$ in heptane solution. 2

NMR data was recorded on a Varian UnityPlus $300 \mathrm{MHz}$, a Varian INOVA $500 \mathrm{MHz}$ or a Bruker AVANCE DPX $400 \mathrm{MHz}$ instrument. ${ }^{1} \mathrm{H}$ and ${ }^{13} \mathrm{C}$ spectra were referenced with respect to the residual solvent signal. ${ }^{29} \mathrm{Si}$ spectra were referenced with respect to tetramethylsilane as an external standard. NMR assignments were confirmed by $2 \mathrm{D} \mathrm{C}-\mathrm{H}$ and $\mathrm{H}-\mathrm{H}$ correlation experiments. NOE experiments were used to determine the identity of the stereoisomers. Figures 1-8 are given as representative spectra.

GC experiments were performed on a Shimadzu GC-17A gas chromatograph fitted with a Rtx-5 fused Crossbond 5\% diphenyl - 95\% dimethyl polysiloxane column (30 meter, $0.25 \mathrm{mmID}, 0.25 \mathrm{umdf})$, using $\mathrm{H}_{2}$ as carrier gas. Detection was by flame ionization and the chromatograms were interpreted using GCsolution software.

\section{Synthesis of $\left[\left\{\left(\mathrm{Me}_{3} \mathrm{Si}\right)_{2} \mathrm{NMgOC}(\mathrm{Ph})=\mathrm{CHMe} \cdot \mathrm{THF}\right\}_{2}\right], 4$}

$0.90 \mathrm{~g} \mathrm{Mg}(\mathrm{HMDS})_{2}(2.62 \mathrm{mmol})$ was dissolved into $10 \mathrm{~mL}$ hexane, followed by the dropwise addition of $0.33 \mathrm{~mL}$ propiophenone $(2.48 \mathrm{mmol})$ in $2 \mathrm{~mL}$ hexane at $20^{\circ} \mathrm{C}$ under a nitrogen atmosphere. The resulting pale yellow solution was stirred for a further 3 hours. Addition of $0.25 \mathrm{~mL}$ THF $(3.16 \mathrm{mmol})$ followed by heating to $60^{\circ} \mathrm{C}$ led to a homogeneous yellow solution. After storing the solution for approximately 2 months

1. Tanner, P. S.; Burkey, D. J.; Hanusa, T. P. Polyhedron 1995, 14, 331-333.

2. Henderson, K. W.; Allan, J. F.; Kennedy, A. R. Chem. Commun. 1997, 1149-1150. 
at $-20^{\circ} \mathrm{C}$, a small number of colorless crystals with a moderate quantity of pale orange solid were deposited from solution. Yield: $360 \mathrm{mg}, 20 \%$.

The NMR data indicated coprecipitation of 4 with $\operatorname{Mg}(\mathrm{HMDS})_{2}$ and the bisenolate, as well as probable partial dismutation in pyridine. Assignments were made possible by comparison of the spectra with independently prepared samples of $\operatorname{Mg}(\mathrm{HMDS})_{2}$ and the bisenolate.

In addition see Figures 1 and 2 for representative ${ }^{1} \mathrm{H}$ NMR spectra from the reaction of $\operatorname{Mg}(\mathrm{HMDS})_{2}$ with propiophenone in $d_{8}$-toluene. Also, the NOE assignments are shown in Figure 3 and 4.

NMR: $\left(\mathrm{C}_{5} \mathrm{D}_{5} \mathrm{~N}\right.$, r.t. $)$

${ }^{1} \mathrm{H}: \delta(\mathrm{ppm})(400 \mathrm{MHz})$ (after 66hrs)

Accurate integrals are given where available for non-overlapping signals. The integral values for the $m, p-\mathrm{CH}$ of the amido(enolate) and bis(enolate) are combined $(5.6 \mathrm{H}$ in total).

Assignments for $(E)$-amido-enolate:

$0.27\left(\mathrm{~s}, 11.0 \mathrm{H}, \mathrm{SiMe}_{3}\right), 1.96\left(\mathrm{~d},=\mathrm{CH}-\mathrm{CH}_{3}\right), 4.60\left(\mathrm{q}, 0.6 \mathrm{H},{ }^{3} J_{\mathrm{HH}}: 7.02 \mathrm{~Hz},=\mathrm{C} \underline{\mathrm{H}}-\mathrm{CH}_{3}\right)$,

7.14 7.58 (m, m, $p-\mathrm{H}$ on Ar), 7.84 (d, $1.2 \mathrm{H},{ }^{3} J_{\mathrm{HH}}: 7.57 \mathrm{~Hz}, o-\mathrm{H}$ on $\left.\mathrm{Ar}\right)$

Assignments for $(Z)$-amido-enolate:

$0.29\left(\mathrm{~s}, 7 \mathrm{H}, \mathrm{SiMe}_{3}\right), 2.10\left(\mathrm{~d},=\mathrm{CH}-\mathrm{CH}_{3}\right), 5.23\left(\mathrm{q}, 0.4 \mathrm{H},{ }^{3} \mathrm{~J}_{\mathrm{HH}}: 6.48 \mathrm{~Hz},=\mathrm{C} \underline{\mathrm{H}}-\mathrm{CH}_{3}\right)$,

7.14 7.58 (m, m, $p$-H on Ar), $8.12\left(\mathrm{~d},{ }^{3} J_{\mathrm{HH}}: 7.97 \mathrm{~Hz}, o-\mathrm{H}\right.$ on Ar)

Assignments for other species:

$\mathrm{Mg}(\mathrm{HMDS})_{2}: 0.18$ (s, 15.9H, $\left.-\mathrm{SiMe}_{3}\right)$

Free THF: $1.47\left(\mathrm{~m}, 8.2 \mathrm{H},-\mathrm{CH}_{2}-\right), 3.54\left(\mathrm{~m}, 8.2 \mathrm{H},-\mathrm{OCH}_{2}-\right)$

Bis(enolate), (E)-isomer:

$7.93\left(\mathrm{~d}, 0.9 \mathrm{H},{ }^{3} J_{\mathrm{HH}}: 7.55 \mathrm{~Hz}, o-\mathrm{H}\right.$ on $\left.\mathrm{Ar}\right), 7.14 \sim 7.58(\mathrm{~m}, \mathrm{~m}, p-\mathrm{H}$ on $\mathrm{Ar}), 4.65\left(\mathrm{q}, 0.4 \mathrm{H},{ }^{3} J_{\mathrm{HH}}\right.$ :

$\left.7.04 \mathrm{~Hz},=\mathrm{CH}-\mathrm{CH}_{3}\right), 1.96\left(\mathrm{~d},=\mathrm{CH}-\mathrm{CH}_{3}\right)$

Bis(enolate), (Z)-isomer:

$8.15\left(\mathrm{~d},{ }^{3} \mathrm{~J}_{\mathrm{HH}}: 7.99 \mathrm{~Hz}, o-\mathrm{H}\right.$ on $\left.\mathrm{Ar}\right), 7.14 \sim 7.58(\mathrm{~m}, \mathrm{~m}, p-\mathrm{H}$ on $\mathrm{Ar}), 5.19$ (q, $0.3 \mathrm{H},{ }^{3} \mathrm{~J}_{\mathrm{HH}}$ :

$\left.6.50 \mathrm{~Hz},=\mathrm{CH}-\mathrm{CH}_{3}\right), 2.09\left(\mathrm{~d},=\mathrm{CH}-\mathrm{CH}_{3}\right)$

${ }^{13} \mathrm{C}: \delta(\mathrm{ppm})(100 \mathrm{MHz})$

Assignments for $(E)$-amido-enolate:

5.2 $\left(\mathrm{SiMe}_{3}\right), 5.6\left(=\mathrm{CH}-\mathrm{CH}_{3}\right), 24.6\left(-\mathrm{CH}_{2}-\right.$ from THF), $66.9\left(-\mathrm{OCH}_{2}\right.$ - from THF), 100.5

$\left(=\underline{\mathrm{CH}}-\mathrm{CH}_{3}\right), 126.8$ (meta-C on Ar), 127.2 (ortho-C on Ar), 128.0 (para-C on Ar), 128.7

(ipso-C on $\mathrm{Ar}), 139.3(-\underline{\mathrm{C}}(\mathrm{O})=\mathrm{C}(\mathrm{H}) \mathrm{Me})$.

Assignments for $(Z)$-amido-enolate: 
$5.2\left(\mathrm{SiMe}_{3}\right), 6.1\left(=\mathrm{CH}-\mathrm{CH}_{3}\right), 24.6\left(-\mathrm{CH}_{2}-\right.$ from THF), $66.9\left(-\mathrm{OCH}_{2}\right.$ - from THF), 101.1 (= $\mathrm{CH}-\mathrm{CH}_{3}$ ), 125.3 (meta-C on Ar), 127.2 (ortho-C on Ar), 127.7 (para-C on Ar), 129.6 (ipso-C on $\mathrm{Ar}), 139.9(-\underline{\mathrm{C}}(\mathrm{O})=\mathrm{C}(\mathrm{H}) \mathrm{Me})$.

\section{Synthesis of $\left[\mathrm{Ca}_{2}\{\mathrm{OC}(\mathrm{Ph})=\mathrm{CHMe}\}_{3} \cdot 6 \mathrm{THF}\right]^{+}\left[\mathrm{Ca}\left\{\mathrm{N}\left(\mathrm{SiMe}_{3}\right)_{2}\right\}_{3}\right]^{-}, 5$}

$0.36 \mathrm{~g}(1 \mathrm{mmol}) \mathrm{Ca}(\mathrm{HMDS})_{2}$ was dissolved into $5 \mathrm{~mL}$ of neat THF under a nitrogen atmosphere and the solution was cooled down to $-78^{\circ} \mathrm{C}$. Then $0.13 \mathrm{~mL}(1 \mathrm{mmol})$ of propiophenone was added dropwise to the cooled solution, followed by stirring for $3 \mathrm{~h}$. Warming up the reaction mixture slowly to room temperature resulted in the formation of a light orange solution. After reducing the volume of the reaction mixture and filtering off any solid impurities, storage of filtrate at $-20^{\circ} \mathrm{C}$ led to the formation of colorless crystals. Yield: $334 \mathrm{mg}, 21 \%$.

The NMR spectra of crystalline 5 revealed partial rearrangement into the bisamide, the bisenolate and the amido(enolate). Assignments were made possible by comparison of the spectra with independently prepared samples of $\mathrm{Ca}(\mathrm{HMDS})_{2}$, the bisenolate and the trisamide anion (complex 6). See Figure 5 for the ${ }^{1} \mathrm{H}$ NMR spectrum of the reaction of $\mathrm{Ca}(\mathrm{HMDS})_{2}$ with propiophenone in $d_{5}$-pyridine. Also see Figure 6 for the ${ }^{1} \mathrm{H}$ NMR spectrum of crystalline 5 in $d_{5}$-pyridine and Figure 7 for the spectrum in $d_{6}$-DMSO.

NMR: $\left(\mathrm{C}_{5} \mathrm{D}_{5} \mathrm{~N}\right.$, r.t. $)$

${ }^{1} \mathrm{H}: \delta(\mathrm{ppm})(500 \mathrm{MHz})$

Accurate integrals are given where available for non-overlapping signals. The integral values for the $m, p-\mathrm{H}$ on $\mathrm{Ar}$ of the amido-enolate and bisenolate are combined $(3.7 \mathrm{H}$ in total).

Assignments for major species: amido-enolate

$0.35\left(\mathrm{~s}, 19.0 \mathrm{H}, \mathrm{SiMe}_{3}\right), 1.85\left(\mathrm{~d}, 3.4 \mathrm{H},=\mathrm{CH}-\mathrm{CH}_{3}\right), 5.11\left(\mathrm{q}, 1 \mathrm{H},{ }^{3} J_{\mathrm{HH}}: 6.45 \mathrm{~Hz},=\mathrm{C} \underline{\mathrm{H}}-\mathrm{CH}_{3}\right)$, 7.10 7.23 (m, $m, p-\mathrm{H}$ on Ar), 7.90 (d, $1.8 \mathrm{H},{ }^{3} \mathrm{~J}_{\mathrm{HH}}: 7.05 \mathrm{~Hz}$, ortho-H on Ar).

Assignments for other species:

$\mathrm{Ca}(\mathrm{HMDS})_{2}: 0.34\left(\mathrm{~s}, 5.6 \mathrm{H}, \mathrm{SiMe}_{3}\right)$

Free THF: $1.63\left(\mathrm{~m}, 2.4 \mathrm{H},-\mathrm{CH}_{2}-\right), 3.67\left(\mathrm{~m}, 2.2 \mathrm{H},-\mathrm{OCH}_{2}-\right)$

Partial THF were lost under vacuum when the crystals were isolated.

Charge-separated species: $0.56\left(\mathrm{~s}, 0.77 \mathrm{H}, \mathrm{Ca}\left(\mathrm{SiMe}_{3}\right)_{3}\right)$

Bisenolate: $1.94\left(\mathrm{~d}, 0.90 \mathrm{H},=\mathrm{CH}-\mathrm{CH}_{3}\right), 5.26\left(\mathrm{q},{ }^{3} J_{\mathrm{HH}}: 6.38 \mathrm{~Hz}, 0.24 \mathrm{H},=\mathrm{CH}-\mathrm{CH}_{3}\right)$,

7.10 7.23 (m, $m, p-\mathrm{H}$ on Ar), 8.15 (d, ${ }^{3} J_{\mathrm{HH}}: 7.16 \mathrm{~Hz}, 0.47 \mathrm{H}$, ortho-H on Ar)

${ }^{13} \mathrm{C}: \delta(\mathrm{ppm})(75 \mathrm{MHz})$

Assignments for major species: amido-enolate

$6.63\left(\mathrm{SiMe}_{3}\right), 13.04\left(=\mathrm{CH}-\mathrm{CH}_{3}\right), 26.27\left(-\mathrm{CH}_{2}\right.$ - from THF), 68.31 (- $\mathrm{OCH}_{2}-$ from THF), $88.09\left(=\mathrm{CH}-\mathrm{CH}_{3}\right), 125.99$ (ortho-C on Ar), 126.26 (para-C on Ar), 128.06 (meta-C on Ar), 146.72 (ipso-C on $\mathrm{Ar}), 160.68(-\underline{\mathrm{C}}(\mathrm{O})=\mathrm{C}(\mathrm{H}) \mathrm{Me})$.

Assignments for other species: 
Charge-separated species: $6.81\left[\mathrm{Ca}\left(\mathrm{SiMe}_{3}\right)_{3}\right]$

The signals corresponding to bisenolate are not reported due to their low concentration in solution.

Dissolution of 5 in the highly polar solvent DMSO- $d_{6}$ was found to favor the formation of the charge-separated species. This allowed comparison of the ${ }^{1} \mathrm{H}$ and ${ }^{29} \mathrm{Si}$ NMR data of 5 and 6.

${ }^{1} \mathrm{H}: \delta(\mathrm{ppm})(400 \mathrm{MHz})\left(\mathrm{DMSO}-d_{6}\right)$

Only one set of signals were obtained, see Figure 7.

$-0.19\left(\mathrm{~s}\right.$, broad, $\left.54.0 \mathrm{H}, \mathrm{SiMe}_{3}\right), 1.69\left(\mathrm{~d}, 9.57 \mathrm{H},=\mathrm{CH}-\underline{\mathrm{CH}}_{3}\right), 1.76\left(\mathrm{~m}, 11.8 \mathrm{H},-\mathrm{CH}_{2}-, \mathrm{THF}\right)$, $3.60\left(\mathrm{~m}, 10.8 \mathrm{H},-\mathrm{OCH}_{2}-, \mathrm{THF}\right), 4.46\left(\mathrm{q}, \operatorname{broad}, 2.73 \mathrm{H},{ }^{3} \mathrm{~J}_{\mathrm{HH}}: 5.71 \mathrm{~Hz},=\mathrm{CH}_{-}-\mathrm{CH}_{3}\right)$, $7.01 \sim 7.18$ (m, broad, 9.41H, m, p-H on Ar), 7.71 (s, broad, $6.45 \mathrm{H}$, ortho-H on Ar).

Partial loss of THF was due to isolation in vacuo during isolation.

${ }^{29} \mathrm{Si}: \delta(\mathrm{ppm})(99 \mathrm{MHz})\left(\mathrm{DMSO}-d_{6}\right)$

$-15.3\left[\mathrm{Ca}\left(\mathrm{SiMe}_{3}\right)_{3}\right]$

\section{Synthesis of $[\mathrm{K} \cdot(18-\mathrm{C}-6) \cdot \mathrm{THF} \cdot \mathrm{tol}]^{+}\left[\mathrm{Ca}\left\{\mathrm{N}\left(\mathrm{SiMe}_{3}\right)_{2}\right\}_{3}\right]{ }^{-}, 6$}

$0.21 \mathrm{~g}(1 \mathrm{mmol}) \mathrm{KHMDS}$ and $0.36 \mathrm{~g}(1 \mathrm{mmol}) \mathrm{Ca}(\mathrm{HMDS})_{2}$ were mixed into $5 \mathrm{~mL}$ of neat THF under a nitrogen atmosphere, followed by stirring at room temperature for 30 min. A solution of $0.26 \mathrm{~g}$ (1 mmol) 18-crown- 6 in $2 \mathrm{~mL}$ THF was then added dropwise to the reaction mixture. After stirring another $0.5 \mathrm{~h}$ and filtering off any solid impurities, the addition of $2 \mathrm{~mL}$ toluene and the storage of filtrate at $-20^{\circ} \mathrm{C}$ led to the formation of colorless crystals. Yield: $316 \mathrm{mg}, 32 \%$.

Also see Figure 8 for the ${ }^{1} \mathrm{H}$ NMR spectrum of crystalline 6 in $d_{6}$-DMSO.

NMR: $\left(\mathrm{C}_{5} \mathrm{D}_{5} \mathrm{~N}\right.$, r.t. $)$

${ }^{1} \mathrm{H}: \delta(\mathrm{ppm})(300 \mathrm{MHz})$

$0.55\left(\mathrm{~s}, 54.0 \mathrm{H}, \mathrm{SiMe}_{3}\right), 1.64\left(\mathrm{~m}, 1.19 \mathrm{H},-\mathrm{CH}_{2}-\right.$ from $\left.\mathrm{THF}\right), 2.24\left(\mathrm{~s}, 1.81 \mathrm{H},-\mathrm{CH}_{3}\right.$ from toluene), $3.47\left(\mathrm{~s}, 26.5 \mathrm{H},-\mathrm{OCH}_{2}\right.$ - from $\left.18-\mathrm{C}-6\right), 3.67\left(\mathrm{~m}, 1.42 \mathrm{H},-\mathrm{OCH}_{2}-\right.$ from $\left.\mathrm{THF}\right)$, 7.17 7.32 (m, 1.61H, Ar-H from toluene).

Partial loss of THF and toluene was due to isolation in vacuo during isolation.

${ }^{13} \mathrm{C}: \delta(\mathrm{ppm})(75 \mathrm{MHz})$

$6.81\left(\mathrm{SiMe}_{3}\right), 21.79\left(-\mathrm{CH}_{3}\right.$ from toluene $), 26.28\left(-\mathrm{CH}_{2}-\right.$ from THF), $68.29\left(-\mathrm{OCH}_{2}-\right.$ from THF), 70.83 (- $\mathrm{OCH}_{2}$ - from 18-C-6), 126.22 (para-C on Ar from toluene), 129.13 (meta$\mathrm{C}$ on Ar from toluene), 129.87 (ortho-C on Ar from toluene), 138.49 (ipso-C on Ar from toluene).

${ }^{1} \mathrm{H}: \delta(\mathrm{ppm})(400 \mathrm{MHz})\left(\mathrm{DMSO}-d_{6}\right)$ 
-0.19 (s, broad, $\left.54.0 \mathrm{H}, \mathrm{SiMe}_{3}\right), 3.55\left(\mathrm{~s}, 25.9 \mathrm{H},-\mathrm{OCH}_{2}-\right.$ from 18-C-6) and trace amount of toluene: 2.29 (s, $-\mathrm{CH}_{3}$ from toluene), 7.12 7.26 (m, Ar-H from toluene).

${ }^{29} \mathrm{Si}: \delta(\mathrm{ppm})(99 \mathrm{MHz})\left(\mathrm{DMSO}-d_{6}\right)$

$-13.9\left[\mathrm{Ca}\left(\mathrm{SiMe}_{3}\right)_{3}\right]$

\section{Synthesis of $\left[\left(\mathrm{Me}_{3} \mathrm{Si}\right)_{2} \mathrm{NCa}\{\mathrm{OC}(\mathrm{Ph})=\mathrm{CHMe}\} \cdot \mathrm{PMDETA}\right], 7$}

$0.36 \mathrm{~g}$ (1 mmol) $\mathrm{Ca}(\mathrm{HMDS})_{2}$ and $0.21 \mathrm{~mL}(1 \mathrm{mmol})$ PMDETA (N,N,N',N",N"pentamethyldiethylenetriamine) were dissolved into $5 \mathrm{~mL}$ of neat THF under a nitrogen atmosphere and the solution was cooled down to $-78^{\circ} \mathrm{C}$. Then $0.13 \mathrm{~mL}(1 \mathrm{mmol})$ of propiophenone, was added dropwise to the cooled solution, followed by stirring for $3 \mathrm{~h}$. Warming up the reaction mixture slowly to room temperature resulted in the formation of a light yellow solution. After reducing the volume of the reaction mixture and filtering off any solid impurities, storage of filtrate at $-20^{\circ} \mathrm{C}$ led to the formation of colorless crystals. Yield: $220 \mathrm{mg}, 43 \%$.

Also see Figure 6 for the ${ }^{1} \mathrm{H}$ NMR spectrum of crystalline 7 in $d_{5}$-pyridine.

NMR: $\left(\mathrm{C}_{5} \mathrm{D}_{5} \mathrm{~N}\right.$, r.t. $)$

${ }^{1} \mathrm{H}: \delta(\mathrm{ppm})(500 \mathrm{MHz})$

Accurate integrals are given where available for non-overlapping signals. The integral values for the $m, p-\mathrm{H}$ on $\mathrm{Ar}$ of the amido-enolate and bisenolate are combined $(5.3 \mathrm{H}$ in total).

Assignments for major species: amido-enolate

$0.36\left(\mathrm{~s}, 18.0 \mathrm{H}, \mathrm{SiMe}_{3}\right), 1.85\left(\mathrm{~d}, 3.2 \mathrm{H},=\mathrm{CH}-\mathrm{CH}_{3}\right), 5.11\left(\mathrm{q}, 1.10 \mathrm{H},{ }^{3} \mathrm{~J}_{\mathrm{HH}}: 6.49 \mathrm{~Hz},=\mathrm{C} \underline{\mathrm{H}}-\right.$ $\left.\mathrm{CH}_{3}\right), 7.11 \sim 7.25(\mathrm{~m}, m, p-\mathrm{H}$ on $\mathrm{Ar}), 7.91\left(\mathrm{~d}, 2.0 \mathrm{H},{ }^{3} \mathrm{~J}_{\mathrm{HH}}: 7.19 \mathrm{~Hz}\right.$, ortho-H on Ar).

Assignments for other species:

$\mathrm{Ca}(\mathrm{HMDS})_{2}: 0.34$ (s, 4.40H, $\left.\mathrm{SiMe}_{3}\right)$

Free PMEDTA: $2.18\left(\mathrm{~s}, 15.7 \mathrm{H},-\mathrm{N}\left(\mathrm{CH}_{3}\right)_{2}\right), 2.25\left(\mathrm{~s}, 4.42 \mathrm{H},-\mathrm{N}\left(\mathrm{CH}_{3}\right)-\right), 2.41 \sim 2.55(\mathrm{~m}$, $\left.10.8 \mathrm{H},-\mathrm{N}-\mathrm{CH}_{2} \mathrm{CH}_{2}-\mathrm{N}-\right)$

Charge-separated species: $0.56\left(\mathrm{~s}, 0.51 \mathrm{H}, \mathrm{Ca}\left(\mathrm{SiMe}_{3}\right)_{3}{ }^{-}\right)$

Bisenolate: $1.95\left(\mathrm{~d}, 1.3 \mathrm{H},=\mathrm{CH}-\mathrm{CH}_{3}\right), 5.26\left(\mathrm{q}, 0.45 \mathrm{H},{ }^{3} J_{\mathrm{HH}}: 6.41 \mathrm{~Hz},=\mathrm{CH}-\mathrm{CH}_{3}\right), 8.15(\mathrm{~d}$, $0.78 \mathrm{H},{ }^{3} \mathrm{~J}(\mathrm{CH}-\mathrm{CH}): 7.24 \mathrm{~Hz}$, ortho-H on $\left.\mathrm{Ar}\right)$

${ }^{13} \mathrm{C}: \delta(\mathrm{ppm})(75 \mathrm{MHz})$

Assignments for major species: heteroleptic dimer of amido-enolate $6.63\left(\mathrm{SiMe}_{3}\right), 13.04\left(=\mathrm{CH}-\mathrm{CH}_{3}\right), 43.49\left(-\mathrm{N}\left(\mathrm{CH}_{3}\right)_{2}\right.$ from PMDETA $), 46.42\left(-\mathrm{N}\left(\mathrm{CH}_{3}\right)-\right.$ from PMDETA), 88.09 ( $=\underline{\mathrm{CH}}-\mathrm{CH}_{3}$ ), 125.97 (ortho-C on Ar), 126.26 (para-C on Ar), 128.04 (meta-C on Ar), 146.73 (ipso-C on $\mathrm{Ar}), 160.69(-\mathrm{C}(\mathrm{O})=\mathrm{C}(\mathrm{H}) \mathrm{Me})$.

Assignments for other species: 
Charge-separated species: $6.82\left[\mathrm{Ca}\left(\mathrm{SiMe}_{3}\right)_{3}\right]$

Signals for bisenolate are not reported due to the low concentration present.

\section{Trapping studies for the $\mathrm{Mg} / \mathrm{Ca}$ enolates:}

See Table 1 for a summary of the trapping studies.

\section{Attempted formation of the silyl-enol-ethers by trapping the magnesium enolates in toluene solution}

$\operatorname{Mg}(\text { HMDS })_{2}$ (1mmol, 0.35g), was dissolved in $5 \mathrm{~mL}$ toluene at ambient temperature under $\mathrm{N}_{2}$. Propiophenone $(0.75 \mathrm{mmol}, 0.1 \mathrm{~mL})$ was added in a dropwise manner over 10 minutes. After stirring for 3 hours, trimethylsilyl chloride (TMSCl) $(4 \mathrm{mmol}, 0.5 \mathrm{ml})$ was then added to the resultant solution. The mixture was stirred for a further 24 hours and $0.5 \mathrm{~mL}$ of the resulting solution was collected from the Schlenk flask and quenched by saturated aqueous $\mathrm{NaHCO}_{3}(5 \mathrm{~mL})$. The quenched reaction mixture was extracted with ether $(5 \mathrm{~mL})$, diluted by THF and analyzed by GC.

\section{Formation of the silyl-enol-ethers by transmetallation of the magnesium enolates in toluene solution}

$\mathrm{Mg}(\mathrm{HMDS})_{2}(1.89 \mathrm{mmol}, 0.65 \mathrm{~g})$, was dissolved in $25 \mathrm{~mL}$ toluene at ambient temperature under $\mathrm{N}_{2}$. Propiophenone $(2.11 \mathrm{mmol}, 0.28 \mathrm{~mL})$ in $1 \mathrm{ml}$ toluene was added into the solution over 10 minutes via a syringe pump. After stirring for 3 hours, the reaction mixture was cooled to $-78^{\circ} \mathrm{C}$ and $n$-BuLi $(6.64 \mathrm{mmol}, 4.1 \mathrm{~mL}$ of a $1.62 \mathrm{M}$ solution in hexanes) was added over $1 \mathrm{~min}$. After stirring for a further $30 \mathrm{~min}$, the solution was allowed to warm to approximately $-30^{\circ} \mathrm{C}$ over 15 minutes, then cooled back to $-78^{\circ} \mathrm{C}$. THF $(5 \mathrm{~mL})$ and TMSCl $(7.56 \mathrm{mmol}, 0.96 \mathrm{~mL})$ were added successively, and the solution was warmed to ambient temperature over 30 minutes. $0.5 \mathrm{~mL}$ of the resulting solution was collected from the Schlenk flask and quenched by saturated aqueous $\mathrm{NaHCO}_{3}(5 \mathrm{~mL})$. The quenched reaction mixture was extracted with ether $(5 \mathrm{~mL})$, diluted by THF and analyzed by GC.

\section{Formation of the silyl-enol-ethers by trapping the magnesium enolates in toluene solution with the addition of HMPA before enolization}

$\operatorname{Mg}(\text { HMDS })_{2}(1 \mathrm{mmol}, 0.35 \mathrm{~g})$, was dissolved in $5 \mathrm{~mL}$ toluene at ambient temperature under $\mathrm{N}_{2}$. HMPA ( $2 \mathrm{mmol}, 0.35 \mathrm{~mL}$ ) was added into the solution followed by the addition of propiophenone $(0.75 \mathrm{mmol}, 0.1 \mathrm{~mL})$ in a dropwise manner over 10 minutes. After stirring for 3 hours, TMSCl (4mmol, $0.5 \mathrm{ml})$ was added to the resultant solution. $0.5 \mathrm{~mL}$ of the resulting solution was collected every $30 \mathrm{~min}$ from the Schlenk flask and quenched by saturated aqueous $\mathrm{NaHCO}_{3}(5 \mathrm{~mL})$. The quenched reaction mixture was extracted with ether $(5 \mathrm{~mL})$, diluted by THF and analyzed by GC. 


\section{Formation of the silyl-enol-ethers by trapping the calcium enolates in toluene solution}

$\mathrm{Ca}$ (HMDS $)_{2}(1 \mathrm{mmol}, 0.36 \mathrm{~g})$, was dissolved in $5 \mathrm{~mL}$ toluene at ambient temperature under $\mathrm{N}_{2}$. Propiophenone $(0.9 \mathrm{mmol}, 0.12 \mathrm{~mL})$ was added in a dropwise manner over 10 minutes. After stirring for 3 hours, TMSCl ( $4 \mathrm{mmol}, 0.5 \mathrm{ml}$ ) was added to the resultant solution. The mixture was stirred for a further 24 hours before $0.5 \mathrm{~mL}$ of the resulting solution was collected from the Schlenk flask and quenched by saturated aqueous $\mathrm{NaHCO}_{3}(5 \mathrm{~mL})$. The quenched reaction mixture was extracted with ether $(5 \mathrm{~mL})$ and $0.5 \mathrm{~mL}$ of the extracts with ether was diluted by $1 \mathrm{~mL}$ THF to be analyzed by GC.

\section{Formation of the silyl-enol-ethers by transmetallation of the calcium enolates in toluene solution}

$\mathrm{Ca}(\mathrm{HMDS})_{2}(1 \mathrm{mmol}, 0.36 \mathrm{~g})$, was dissolved in $5 \mathrm{~mL}$ toluene at $0^{\circ} \mathrm{C}$ under $\mathrm{N}_{2}$. A toluene solution $(3 \mathrm{~mL})$ of propiophenone $(0.75 \mathrm{mmol}, 0.1 \mathrm{~mL})$ was added into the mixture using a syringe pump over $2 \mathrm{~h}$. After stirring for a further 1 hour, the reaction mixture was cooled to $-78^{\circ} \mathrm{C}$ and $n$ - BuLi $(3.5 \mathrm{mmol}, 2.1 \mathrm{~mL}$ of a $1.68 \mathrm{M}$ solution in hexanes) was added over 1 min. After stirring for a further $30 \mathrm{~min}$, the solution was allowed to warm to $0^{\circ} \mathrm{C}$ over 15 minutes. TMSCl $(4 \mathrm{mmol}, 0.5 \mathrm{~mL})$ and THF $(2 \mathrm{~mL})$ were added successively and $0.5 \mathrm{~mL}$ resulting solution was collected from the Schlenk flask and quenched by saturated aqueous $\mathrm{NaHCO}_{3}(5 \mathrm{~mL})$. The quenched reaction mixture was extracted with ether $(5 \mathrm{~mL})$, diluted by THF and analyzed by GC.

\section{Formation of the silyl-enol-ethers by trapping calcium enolates in THF solution}

$\mathrm{Ca}$ (HMDS $)_{2}(1 \mathrm{mmol}, 0.36 \mathrm{~g})$, was dissolved in $5 \mathrm{~mL}$ THF at $0^{\circ} \mathrm{C}$ under $\mathrm{N}_{2}$. Propiophenone $(0.9 \mathrm{mmol}, 0.12 \mathrm{~mL})$ was added in a dropwise manner over 10 minutes. After stirring for 0.5 hour, TMSCl $(4 \mathrm{mmol}, 0.5 \mathrm{ml})$ was added to the resultant solution. After stirring for $30 \mathrm{~min}, 0.5 \mathrm{~mL}$ resulting solution was collected from the Schlenk flask and quenched by saturated aqueous $\mathrm{NaHCO}_{3}(5 \mathrm{~mL})$. The quenched reaction mixture was extracted with ether $(5 \mathrm{~mL})$, diluted by THF and analyzed by GC.

\section{Formation of the silyl-enol-ethers by trapping calcium enolates in pyridine solution}

$\mathrm{Ca}$ (HMDS) $)_{2}$ (1mmol, 0.36g), was dissolved in $5 \mathrm{~mL}$ pyridine at $0^{\circ} \mathrm{C}$ under $\mathrm{N}_{2}$. Propiophenone $(0.9 \mathrm{mmol}, 0.12 \mathrm{~mL})$ was added in a dropwise manner over 10 minutes. After stirring for $15 \mathrm{~min}, \mathrm{TMSCl}(4 \mathrm{mmol}, 0.5 \mathrm{ml})$ was added to the resultant solution. After stirring for $15 \mathrm{~min}, 0.5 \mathrm{~mL}$ resulting solution was collected from the Schlenk flask and quenched by saturated aqueous $\mathrm{NaHCO}_{3}(5 \mathrm{~mL})$. The quenched reaction mixture was extracted with ether $(5 \mathrm{~mL})$, diluted by THF and analyzed by GC. 
Table 1. GC results of trapping the Mg/Ca enolates:

\begin{tabular}{|c|c|c|c|c|c|c|c|}
\hline No. & Base & Solvent & $\begin{array}{c}\text { Trapping } \\
\text { Time }\end{array}$ & Additives & $\left.\mathbf{T} \mathbf{~}^{\circ} \mathbf{C}\right)$ & $\begin{array}{c}\text { Conversion } \\
\mathbf{( \% )}\end{array}$ & $\mathbf{E} / \mathbf{Z}$ \\
\hline $\mathbf{1}$ & $\mathrm{Mg}(\mathrm{HMDS})_{2}$ & Toluene & $24 \mathrm{~h}$ & none & r.t & 0 & - \\
\hline $\mathbf{2}$ & $\mathrm{Mg}(\mathrm{HMDS})_{2}$ & Toluene & $1 \mathrm{~h}$ & ${ }^{\mathrm{n}} \mathrm{BuLi}+\mathrm{THF}$ & r.t. & 96 & $63 / 37^{*}$ \\
\hline $\mathbf{3}$ & $\mathrm{Mg}(\mathrm{HMDS})_{2}$ & Toluene & $1 \mathrm{~h}$ & $\begin{array}{c}\text { HMPA } \\
\text { (before } \\
\text { enolization) }\end{array}$ & r.t. & $>99$ & $2 / 98$ \\
\hline $\mathbf{4}$ & $\mathrm{Ca}(\mathrm{HMDS})_{2}$ & Toluene & $24 \mathrm{~h}$ & none & r.t. & 55 & $12 / 88$ \\
\hline $\mathbf{5}$ & $\mathrm{Ca}(\mathrm{HMDS})_{2}$ & Toluene & $0.5 \mathrm{~h}$ & ${ }^{\mathrm{n}} \mathrm{BuLi}+\mathrm{THF}$ & $0^{\circ} \mathrm{C}$ & $>99$ & $60 / 40$ \\
\hline $\mathbf{6}$ & $\mathrm{Ca}(\mathrm{HMDS})_{2}$ & $\mathrm{THF}$ & $0.5 \mathrm{~h}$ & none & $0^{\circ} \mathrm{C}$ & $>99$ & $4 / 96$ \\
\hline $\mathbf{7}$ & $\mathrm{Ca}(\mathrm{HMDS})_{2}$ & Pyridine & $0.5 \mathrm{~h}$ & none & $0^{\circ} \mathrm{C}$ & 92 & $2 / 98$ \\
\hline
\end{tabular}

The trapped ratio corresponded with the $E / Z$ ratio determined in solution by ${ }^{1} \mathrm{H} N M R$ spectroscopy. 

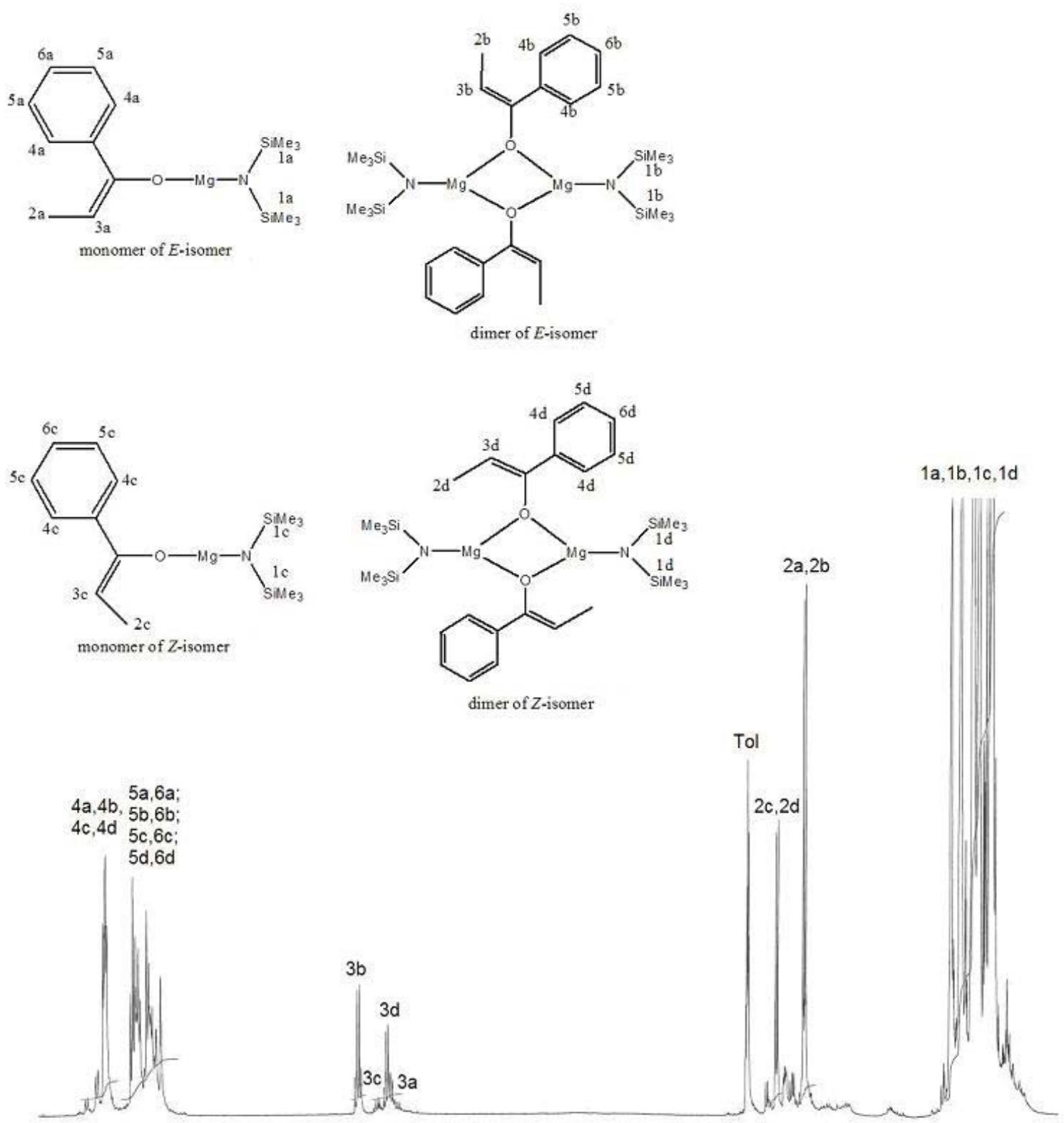

Figure 1. ${ }^{1} \mathrm{H}$ NMR spectrum of the reaction between $\mathrm{Mg}(\mathrm{HMDS})_{2}$ and 0.75 eq. propiophenone in toluene- $d_{8}$ (after 3 hours) $-400 \mathrm{MHz}, 300 \mathrm{~K}$ 

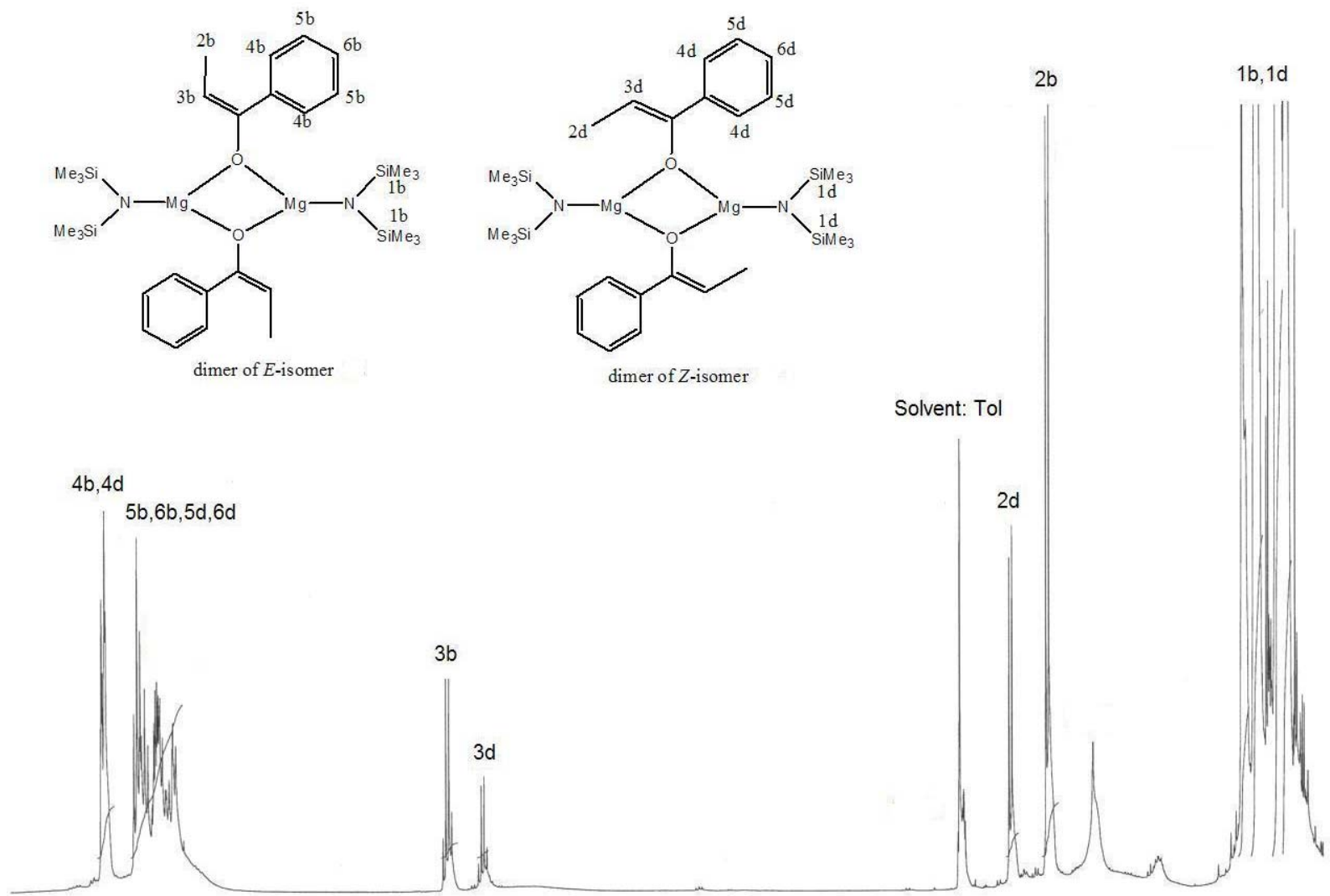

3

ppm

Figure 2. ${ }^{1} \mathrm{H}$ NMR spectrum of the reaction between $\operatorname{Mg}(\mathrm{HMDS})_{2}$ and 0.75 eq propiophenone in toluene- $d_{8}$ (after 66 hours) $-400 \mathrm{MHz}, 300 \mathrm{~K}$ 
Nuclear Overhauser (NOE) experiments were carried out on $\left[\left\{\mathrm{Mg}\{(E):(\mathrm{Z})-\mathrm{OC}(\mathrm{Ph})=\mathrm{C}(\mathrm{H}) \mathrm{Me}\}\left\{\mathrm{N}\left(\mathrm{SiMe}_{3}\right)_{2}\right\}\right\}_{2}\right]$ in order to unambiguously assign the amidomagnesium enolate geometry.

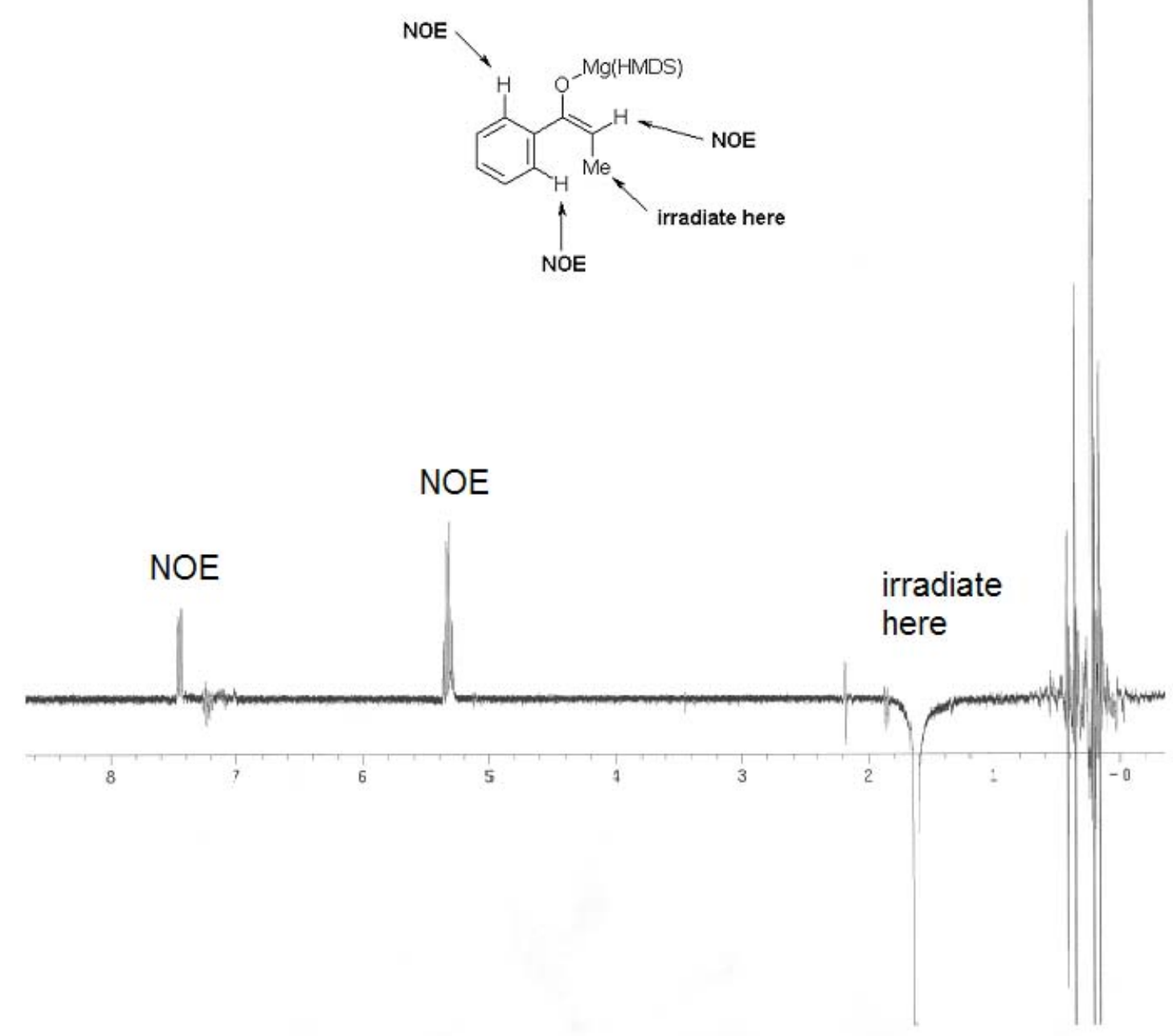

Figure 3. $\mathrm{NOE}$ spectrum of $\left[\left\{\mathrm{Mg}\{(E):(\mathrm{Z})-\mathrm{OC}(\mathrm{Ph})=\mathrm{C}(\mathrm{H}) \mathrm{Me}\}\left\{\mathrm{N}\left(\mathrm{SiMe}_{3}\right)_{2}\right\}\right\}_{2}\right]$ (after 66 hours) upon irradiation at $\delta 1.61-300 \mathrm{MHz}$, toluene- $d_{8}, 300 \mathrm{~K}$ 


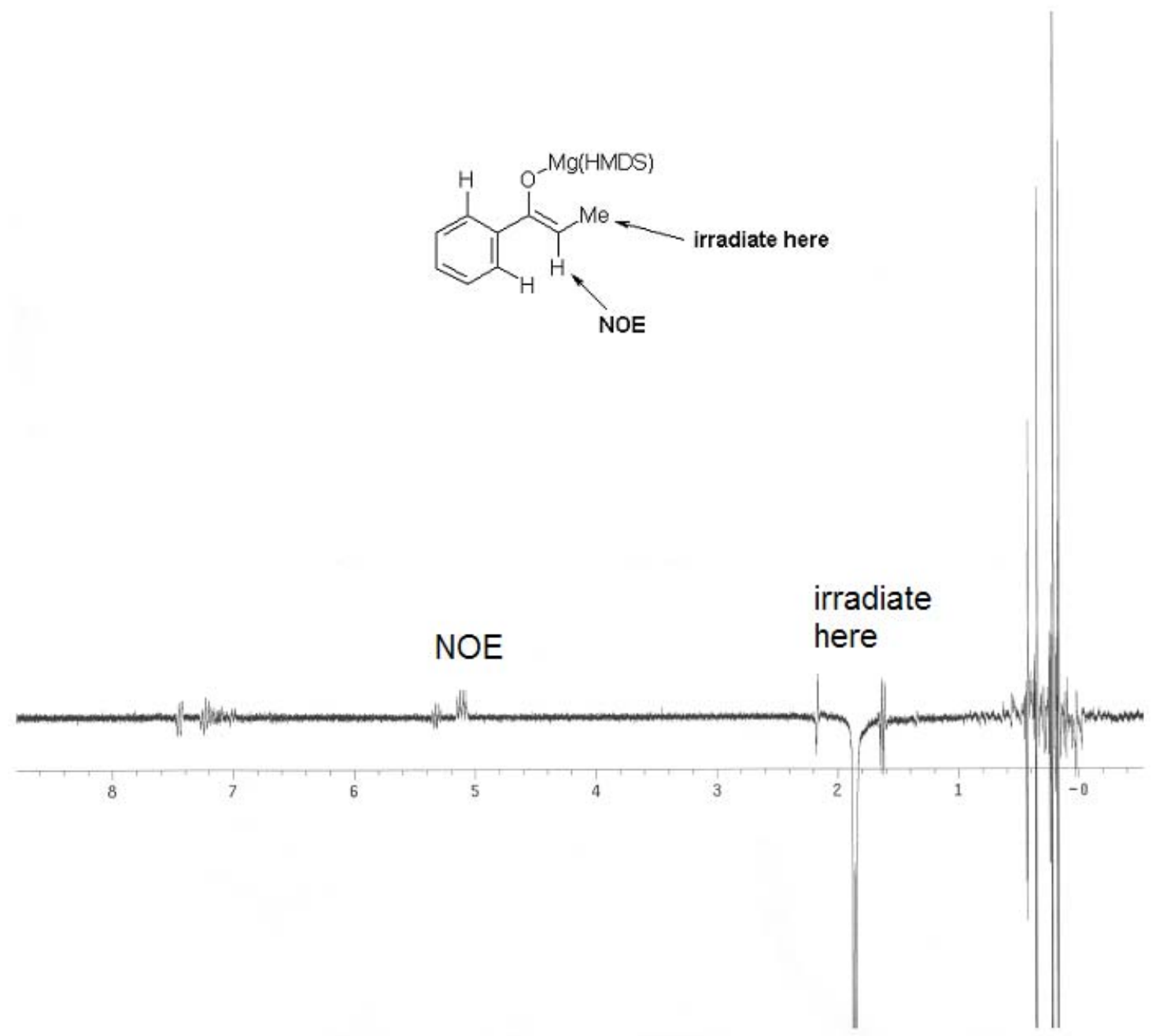

Figure 4. NOE spectrum of $\left[\left\{\mathrm{Mg}\{(E):(\mathrm{Z})-\mathrm{OC}(\mathrm{Ph})=\mathrm{C}(\mathrm{H}) \mathrm{Me}\}\left\{\mathrm{N}\left(\mathrm{SiMe}_{3}\right)_{2}\right\}\right\}_{2}\right]$ (after 66 hours) upon irradiation at $\delta 1.84-300 \mathrm{MHz}$, toluene- $d_{8}, 300 \mathrm{~K}$ 

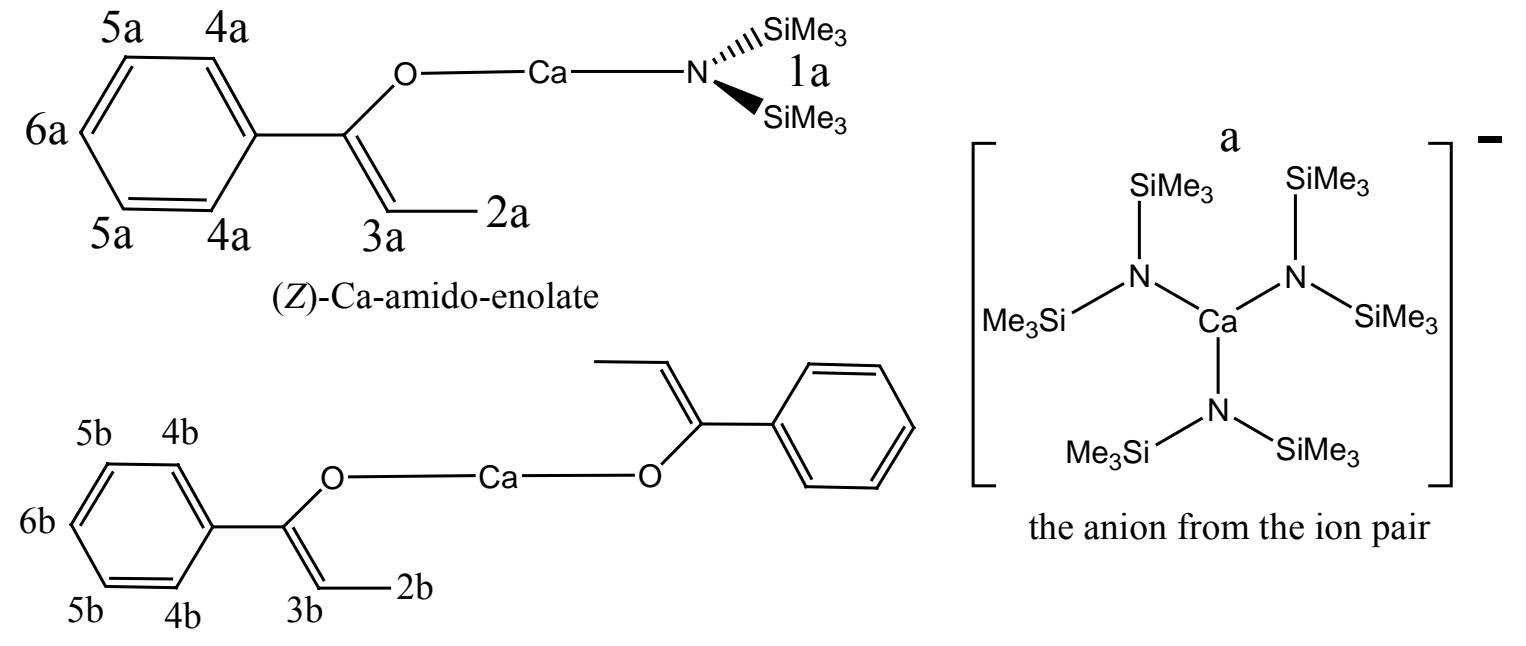

the anion from the ion pair

(Z)-Ca-bisenolate

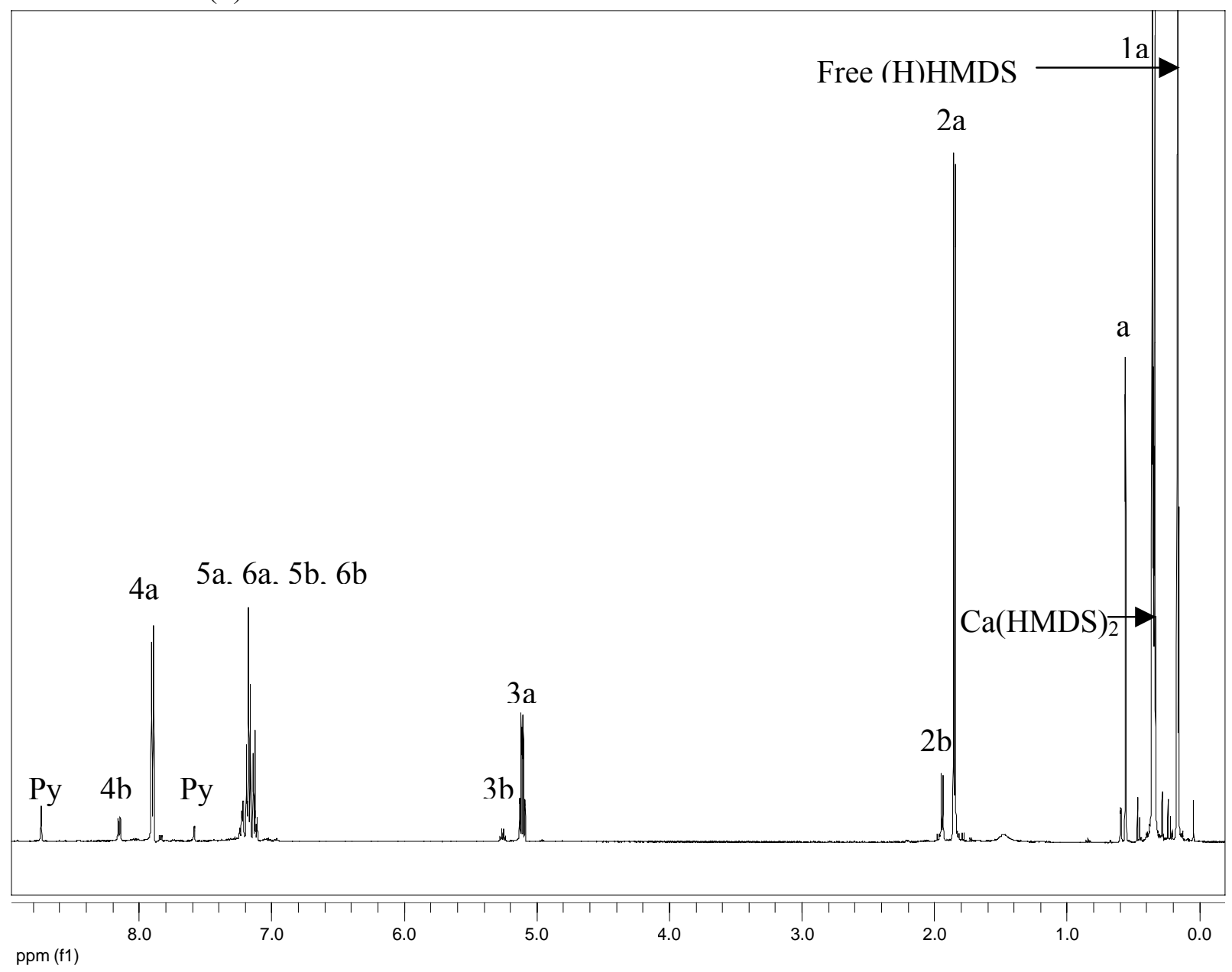

Figure 5. ${ }^{1} \mathrm{H}$ NMR spectrum of the reaction between $\mathrm{Ca}(\mathrm{HMDS})_{2}$ and 1 eq. propiophenone in pyridine- $d_{5}$ (after $\left.15 \mathrm{~min}\right)-500 \mathrm{MHz}, 300 \mathrm{~K}$ 


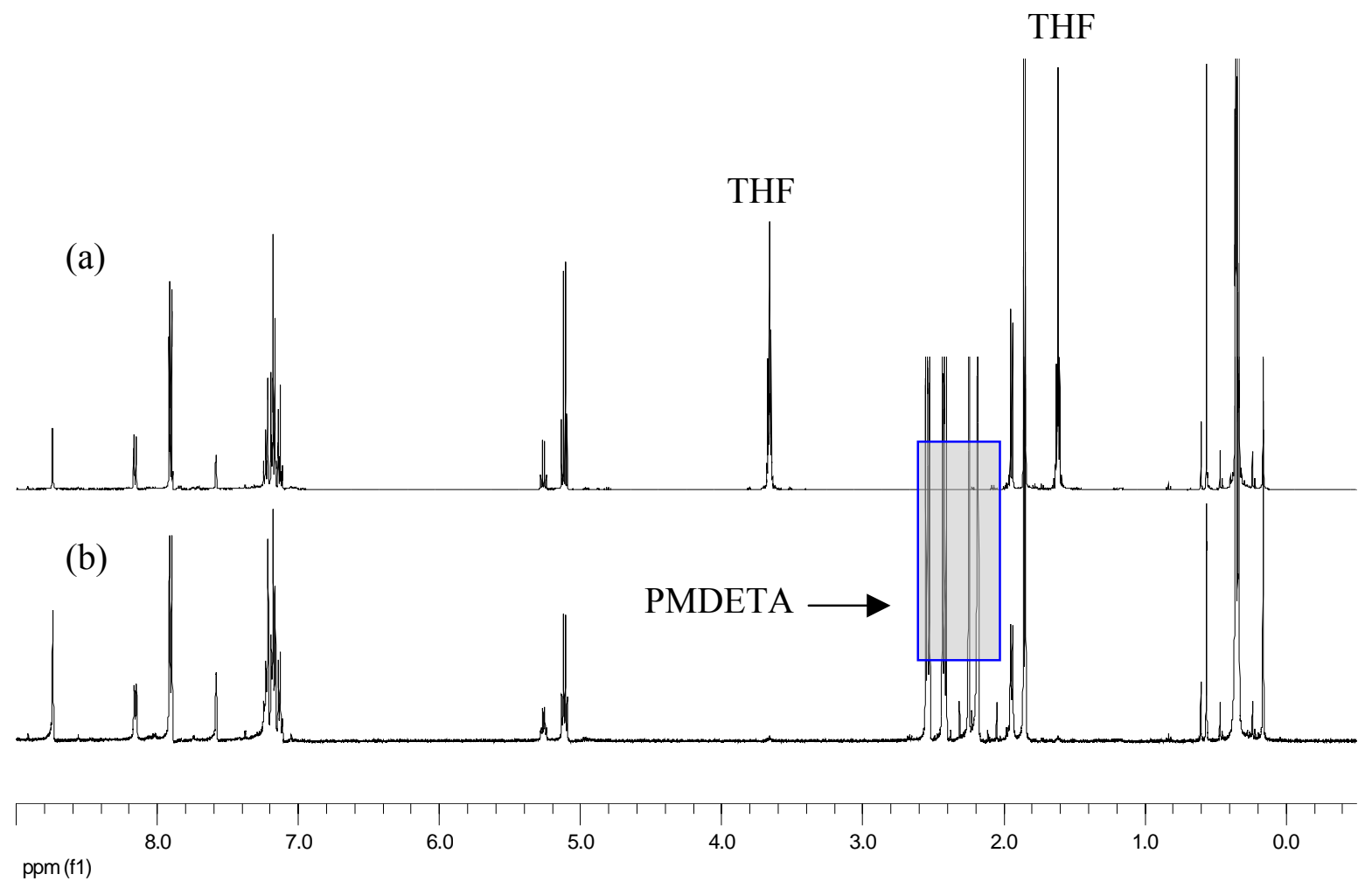

Figure 6. 1HNMR spectra of (a) crystals of the charge-separated species 5 and (b) crystals of the amidocalcium enolate 7 in pyridine- $d_{5}$. 

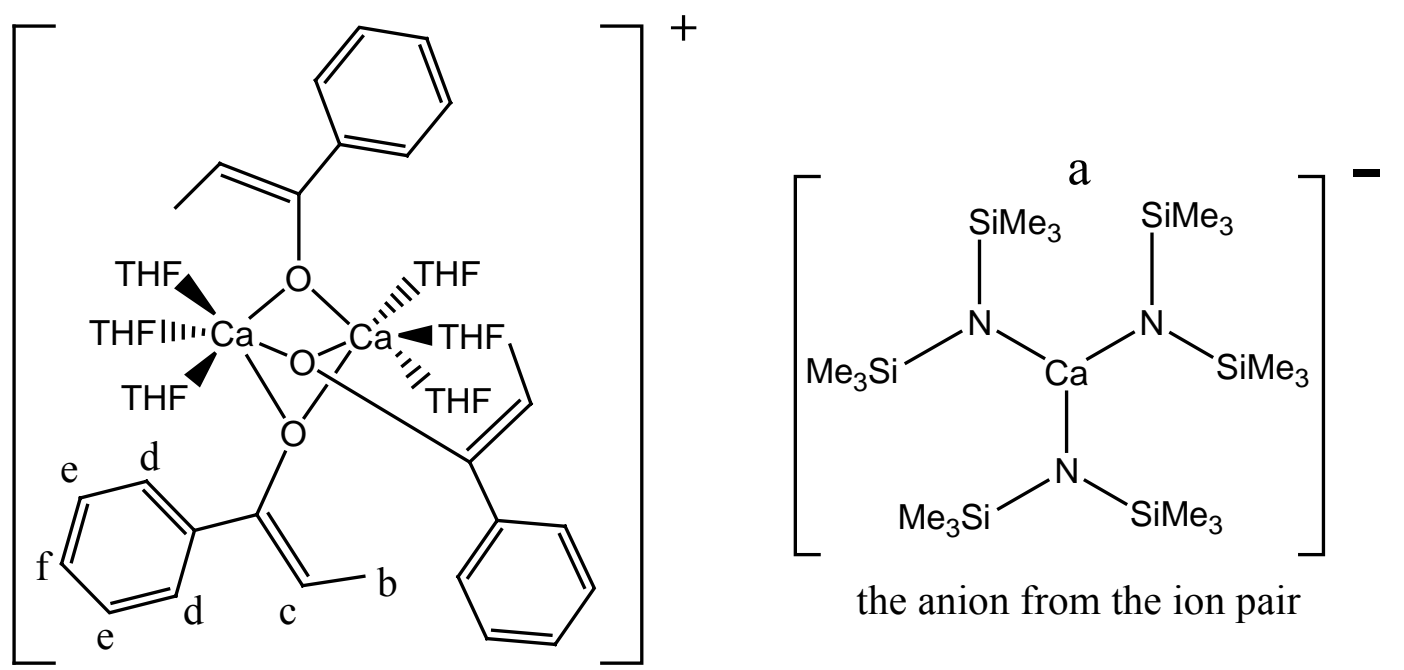

the anion from the ion pair

the cation from the ion pair

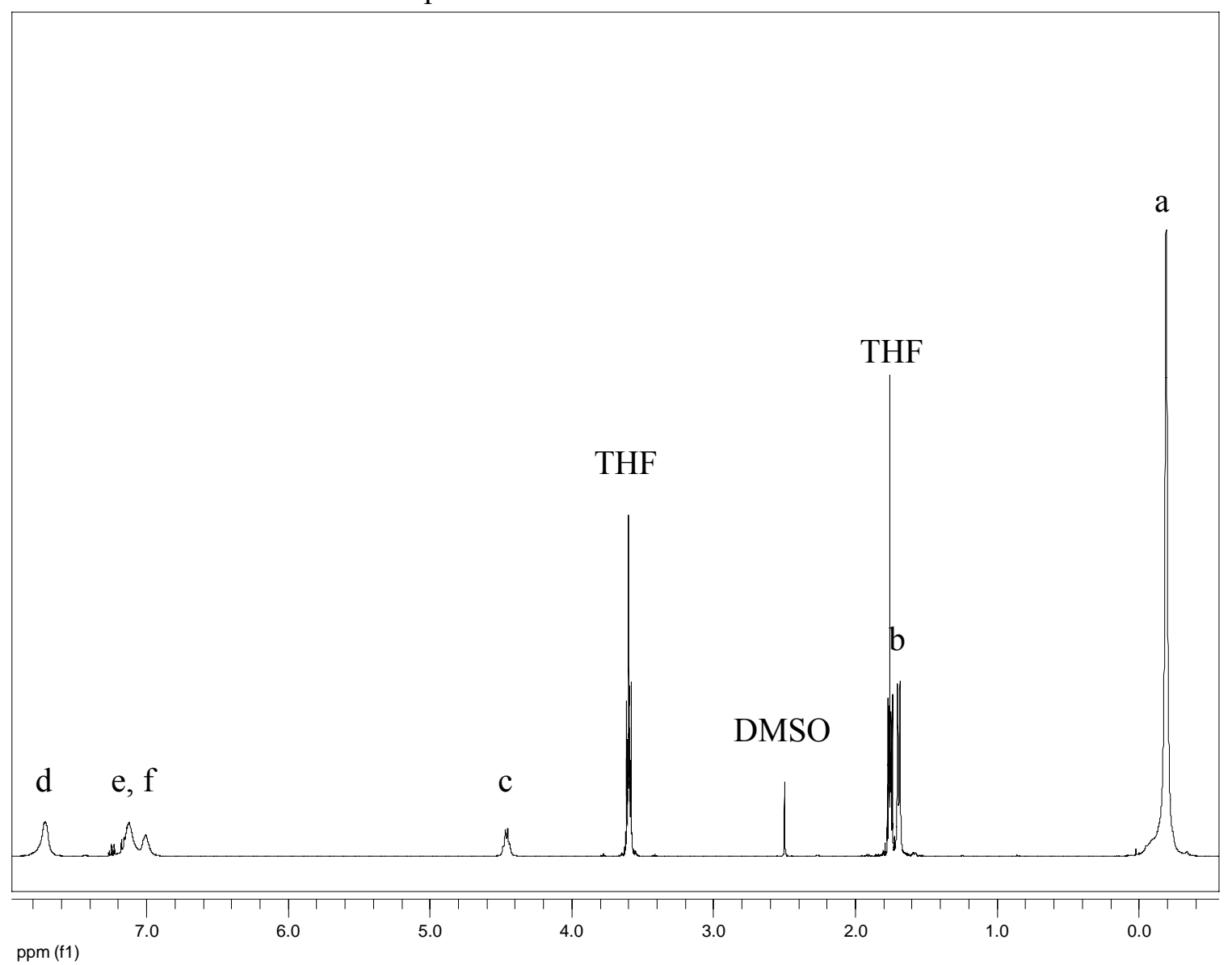

Figure 7. ${ }^{1} \mathrm{HNMR}$ spectra of crystals of the charge-separated species 5 in DMSO- $d_{6}$, $400 \mathrm{MHz}, 300 \mathrm{~K}$. 

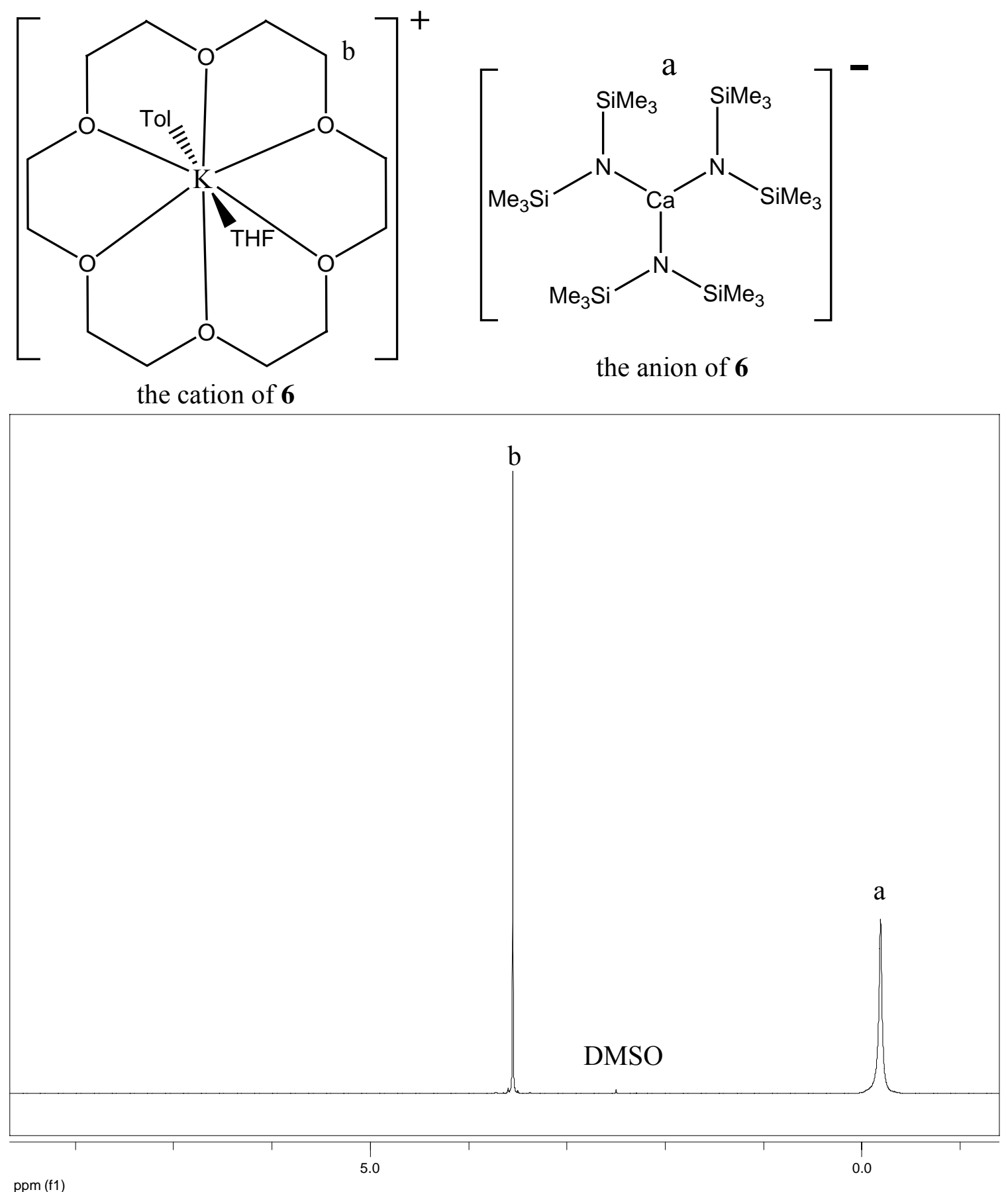

Figure 8. ${ }^{1} \mathrm{HNMR}$ spectra of crystals of the charge-separated species 6 in $d_{6}$-DMSO- $d_{6}$, $400 \mathrm{MHz}, 300 \mathrm{~K}$. 